\title{
Network Pattern of Regional Election Commission (KPUD) Pekanbaru City Increasing Political Participation in Society
}

\author{
Yusri Munaf \\ Dosen Ilmu Pemerintahan FISIPOL \\ Universitas Islam Riau \\ Email : Yusri.munaf@yahoo.co.id
}

\begin{abstract}
Achieving a legitimate democracy with a high level of participation through the holding of regional head elections can not be relied upon only in the General Election Commission. Strengthening of government networks is needed to increase community participation. This paper discusses how the structure of the network formed in the implementation of regional head election in Pekanbaru City. Using network theory according to Povan and Kenis (2008) with three forms of network structure: PGN, organizational leaders (LOG), and regulated network administration (LOG). Based on the results of the analysis, the network formed strongly influence the level of political participation of the community in the election.
\end{abstract}

Keywords: Network, Government, Elections, Head of Region

\section{INTRODUCTION (HEADING 1)}

The holding of qualified general elections is needed as a means of realizing the people's sovereignty in the government of a democratic state based on Pancasila and the 1945 Constitution of the State of the Republic of Indonesia. To improve the quality of elections that can ensure the implementation of the political rights of the community, have integrity, capability, and accountability. This is a consideration of the formation of the Law on the Organizer of the General Election.

In order for the elections to really produce democratic government, the elections should be held by an independent and impartial state institution. Therefore, KPU as an election organizer in Indonesia must always adhere to existing legislation, code of ethics and order of KPU. The duties and powers of the KPU in organizing the elections are not solely related to the parties participating in the election, but also with the public as voters in the election.

Voter participation is very important in determining the success of the election. To that end, then political education becomes a necessity to increase people's political knowledge in order to participate maximally in the delivery of state life. In this regard, the KPU must also socialize the politics to the public to be willing to exercise their voting right at the time the voting is held

Based on data from KPUD Kota Pekanbaru, the level of public participation in Pekanbaru City is the lowest compared to 11 other districts / cities in Riau Province. Voting for the
Direct Election of Regional Head (Pilkada) Pekanbaru which was held on February 15, 2017 and then, simultaneously with 100 other regions in Indonesia in general took place safely and smoothly. The General Election Commission (KPU) of Pekanbaru City set the target of voter turnout in this election at 77.5 percent. However, based on the realcount done Media Center FIAT Data that was launched through the page $\mathrm{http} / / /$ rapidtelecount.com/ only 287,436 votes incoming votes from all Voting Places (TPS) in Pekanbaru which amounted to 1796. Meanwhile, the Permanent Voter List (DPT) of 2017 Regional Head Election Pekanbaru set by Plenary Meeting of KPU Pekanbaru in December 2016 then amounted to 572,029 people. That is, there are 284,593 voters who do not exercise their right to vote for various reasons and reasons. Referring to the data, the percentage of voters set by KPU Pekanbaru clearly did not reach the target, even the number is fairly far, only 50.25 percent.

In this paper, the authors offer solutions in the form of strengthening the network pattern of KPUD Pekanbaru in increasing the political participation of the community, resulting in the election of regional heads that are legitimated procedurally or substantially.

\section{Network Patterns}

In a network there are two important parts of network structure, namely actors (nodes) and relationships between actors (links). Actors are not always individuals, but can also be organizations. Bebagai relationship direction and interaction between network actors are forming a pattern so that to know struktu what network patterns are formed must be based on interaction patterns that occur.

The network pattern is useful to describe the relationship structure and position of the actor in the network. Through the network pattern can be known several things including: the structure of a network, how closely intensive members of the network interact with each other, how the pattern of interaction between members in the network, and how the position of actors inside network, whether as a determinant or as a liaison (Eriyanto, 2014) [1].

In the network pattern there are relationships such as coordination, communication, negotiation and others and able 
to reflect their respective roles. Through the assessment of network patterns that are formed it can be analyzed more clearly and objectively so that it can be useful for organizations solve problem problems and achieve its goals. (Subhan, 2017). [2].

Network patterns by Kenis and Provan (2008) can be categorized based on whether the network has an intermediary or without intermediaries. In one particular condition, the network can be fully governed by the individual organization that fills the network. Each organization interacts with other participating organizations to make operational and strategic decisions about how networks work to produce highly-decent and decentralized network features. Interaction and collaboration take place without intermediaries, but directly interact with each other based on the interests and goals to be achieved. This network pattern is called Self Governance Network (SGN). [3].

While on the other extreme, a network can involve a very important intermediary of existence because it is very centralistic. In this network, the direct relationship between participants' organizations is relatively small because of the role of brokers (intermediaries). The network can take place because there is one organization that governs the network by playing a central function either as a leader or a liaison between participants. This network pattern is called the Lead Organization Network (LON).

Among the two extream systems, there is one combination pattern that can occur when one organization runs a number of key network activities (leads) but the other activities are run by other participant organizations (shared). This pattern is known as Network Adminsitrative Organization (NAO).

These three patterns can be formed in an organizational network process where there are two extreme patterns of SGN and LON, plus a combination pattern of NAO. The net pattern is not static but tends to dynamic based on the dynamics of the interaction. Each has advantages and disadvantages of staying tailored to what criteria are needed.

These three patterns of governance networks are broadly distinguished by the amount, density and the same setrality as is generally examined in social network analysis (Wasserman and Faust, 1994). [4]. 1994:4).

\section{Regional Election Commission}

The elections were held with the aim of selecting representatives of the people and regional representatives, and to form a democratic, strong government and gaining popular support in order to realize the national goals as the 1945 Constitution of 1945. Haris (1998: 10) political education for the people who are direct, open, missal, which is expected to educate political understanding and increase public awareness about democracy. [5].

The regional head is a public or political office achieved through a political mechanism based on a legal system, election representation or through direct election. Head of Region in the context of Indonesia is the governor as the head of the province, the regent as the head of the district, or the mayor as the head of the city area.

The General Elections Commission is an institution elected and stipulated under the law as the organizer of the General Election, which at the outset of its formation, the General Elections Commission (KPU) is a nonpartisan institution and most of the Universities and NonGovernmental Organizations (NGOs) that actually represent every institution in the network structure. The Regional General Elections Commission (KPUD) is a subordinate General Elections Commission (KPU) which serves to hold elections in stages (Wahidin, 2008). [6]

The provisions giving birth to the General Elections Commission (KPU) are contained in article 22E of the 1945 Constitution of the State of the Republic of Indonesia in chapter VIIB General Election which is the result of the third amendment of 2001. Article 22E paragraph (5) states that "Elections are held by a commission national elections, permanent and independent ". In this case, the name of the election commission has not yet shown a definite name, but it is the basis that the government is independent of the KPU in charge of holding the General Elections as an independent organ in its performance.

The election of the Regional Head in the Regency / City is organized by the Regional General Election Commission. The implementation of good Regional Head election is not enough just from how the General Elections Commission works, but it must also be followed by the awareness and high level of community participation. The level of community participation is influenced by how the institutions of the Regional General Elections Commission direct community participation, and the level of public participation also affects whether or not the results of the election results are obtained.

Public participation in Pekanbaru City, when viewed from the age level, it can be seen that the community who participated in the implementation of the election of Head of Region comes from various age above 17 years. In this case the people who have met the applicable requirements and registered as voters have the right and obligation to participate in the election of the regional head. The Regional Election Commission is an institution that has been established as the organizer of the general election, as well as the election of the Regional Head. During the election of the Regional Head, the General Election Commission shall be tasked with carrying out the preparatory activities of regional head elections, planning activities, and determining the election result of the Regional Head. As the organizer of the implementation of the General Election and the Election of Regional Head, the success rate of the implementation of the General Election and the Regional Head Elections shall be determined by the organizer.

\section{Weak Network Pattern Causes Low Participation Political Society \\ Political participation of the community is a citizen} activity that aims to influence the political decision making by a person in his position as a citizen. The political participation of the community is voluntary, not mobilized by the state or 
the ruling party. The participation of citizens is based on high expectations about the quality of citizens and their desire to engage in public life. In this case citizens are required to have more democratic values and a sense of freedom to participate in public issues.

Political participation according to Herbert McClosky is the voluntary activities of the community through which they take part in the process of electing the ruler, and directly or indirectly, in the process of forming public policy (Budiarjo, 2008: 368). It is primarily concerned with actions aimed at influencing government decisions, even though the main focus is broader namely attempts to influence authoritative value allocation for society. Political participation can also be defined as a political stance that includes all activities or activities that have political relevance or affect only government officials in decision-making. [7]

Particularly in Kota Pekabaru, the writer analyzed the low level of voter participation in the 2017 Regional Head Election this time because there are 3 important factors that are background, namely:

1. The first factor is the organizer, starting from the Regional Election Commission (KPUD), Election Supervisory Board and other organizers do not maximize the network work. Sectoral ego problem becomes obstacle of network pattern formed so as to bring broker (intermediary) that is successful team of candidate pair to play transactional politics that hardly proved by Election Supervisory Board.

2. The second factor is the community apathy towards the implementation of elections and some even do not care at all. We see, when Pilkada 9 districts / cities before, the level of voter participation is quite high, but in this Pilkada even decreased. The lack of a measurable and focused network pattern for the purpose of forming a rigid pattern, the process of running values is only played by political actors in a separate network pattern with participants.

3. The third factor is socialization, either organizers or from each candidate pair. Weak socialization conducted by the organizers is usually very scientifically measurable, and can be seen to the impact on the number of pasrtisipasi voters. How socialization is done to the community, whether it is really up to or just to qualify. In addition, the candidate pairs are not maximized in conducting socialization and campaigns in the community, so that people do not know who the candidates will choose. If the candidate pairs are intense to come to the community, then the public will also be very enthusiastic to try to win the candidate, by coming to the TPS and selecting the candidate concerned.

\section{Strategy for Strengthening Network Pattern of KPUD Pekanbaru}

Pekanbaru City has a heterogeneous community and has different background in terms of culture, education and welfare level into consideration in preparing the work program of KPUD Kota Pekanbaru. This is the rationale of some activities (events) that will be implemented in each subdistrict, so it needs to embrace network actors who are able to penetrate some differences that exist in the community and able to convey information or messages to be conveyed to the community as a whole.

The right network pattern to increase community participation is the Self Governance Network (SGN). In one particular condition, the network can be fully governed by the individual organizations that fill the network, for example in this case is holding the community leaders in each District. Those with strong influence in the community will interact with other communities to make operational and strategic decisions about how networks work to produce a structured and decentralized network. Interaction and collaboration take place without intermediaries, but directly interact with each other based on the interests and goals to be achieved. This is the original characteristic of society in general.

KPUD Pekanbaru can implement socialization agenda by maximizing social capital which can be done in several stages.

1. Administration and Secretariat

a) Posko Setup

Form of activities in the sub-district post in the form of preparing information as a place of media center and discussion.

b) Website creation

Form of activities by setting up the website as a medium of socialization in cyberspace. KPUD Pekanbaru City can use the website in order to convey information pengenggaan general elections and electoral services to the public election.

c) Media cooperation

The form of activities is to strengthen the network by building cooperation between the Election Commission with print media and electronic media to blow up the media. The target of this activity is the existence of information about the implementation of elections continuously blow up in print and electronic media with the duration of time is maximized every time.

\section{Initial Socialization}

a) Distribution of stickers per sub-district.

The form of activity is to spread stickers in each region that becomes the voting area. The target of this activity is the attaching of stickers in each house in the area of voters.

b) Voter Data Collection.

The form of activity is to conduct voter data collection in the area of voters. The objective of this activity is to collect primary and secondary data appropriately.

c) Training of the organizing team The form of activities is to conduct a short training to the team of recorders with the target activity 
terformatnya correct data collection to the team who came to the field

d) Installation of Billboards.

The form of activity is to install a billboard at a strategic angle with the target of billboards installed in the strategic corners in the electorate.

e) Survey geographical location.

The form of this activity is Down to the random selection area to see in real geographical conditions as a reference for making the next strategic plan. The objective of the activity is to collect real information about geographical conditions

3. Data Input

a) Mapping the initial voters

The form of activities is to conduct initial mapping of community leaders and youth leaders of supporters and non-voters. The objective of this activity is to obtain information in real condition base and non support base as reference of activity plan next.

b) Bapping mapping of voter areas

The form of activity is to conduct initial mapping of voter base in voter area. The objective of this activity is to obtain information in real condition of base and non base of participation.

c) Personal data of voters per Head of Family.

This form of activity is to input personal data of voters to be used as data persuasive approach through SMS Box and Wa. Activity targets are the collection of primary data voters for reference materials approach via SMS Box and Wa.

\section{Activity}

a) Persuasive approach of community leaders and youth leaders.

The form of activities is to conduct a persuasive and personal approach to youth and community leaders to participate in local elections.

b) Seminars for high school students (beginner voters). The form of this activity is conducting seminar activities with the theme of adolescents in the School as a medium of socialization of candidates to beginner voters. The target of this activity is the implementation of one time activity in high school in the first semester.

c) Down to mosques, markets and schools.

The form of this activity is the candidate head of the region to conduct activities with the format without the concept present in the Mosque for praying in congregation, present in coffee shops /markets to shop and in school as a builder ceremony during the campaign period. The targets of this activity are the general public for the development of opinions, imagery, and the introduction of candidates for regional heads.

\section{Conclusion}

Voter participation is very important in determining the success of the election. KPU as an election organizer in Indonesia must always adhere to existing legislation, code of ethics and order of KPU. The duties and powers of the KPU in organizing elections are not solely related to the parties participating in the election, but also with the public as voters in the election.

The network pattern describes the relationship structure and position of the actor in the network. In Pekanbaru City, the General Elections Commission plays a significant role in increasing community participation, but the fact that the level of community participation in Pekanbaru City compared to 11 regencies / cities in Riau Province shows weak legitimacy in Pekanbaru City. This is because the KPU Pekanbaru not maximal in the strengthening of network patterns, because the network is dominated by the external network of political parties and team suskes candidate pair of regional head. Suggestion in this research is need to strengthen network pattern in the form of Self Governance Network (SGN). Where the network pattern can be categorized based on whether the network has an intermediary or without an intermediary. In one particular condition, the network can be fully governed by the individual organization that fills the network. Each organization interacts with other participating organizations to make operational and strategic decisions about how networks work to produce highly-decent and decentralized network features. Interaction and collaboration take place without intermediaries, but directly interact with each other based on the interests and goals to be achieved. KPUD Pekanbaru can implement socialization agenda by maximizing social capital which can be done in several stages of administrative and secretariat consolidation, initial socialization intensity, data input optimization, and implementation of activity.

\section{Reference}

[1] Eriyanto. 2014. Analisis Jaringan Komunikasi Strategi Baru dalam Penelitian Ilmu Komunikasi dan Ilmu Sosial lainnta. Jakarta. Kencana. Halaman 15

[2] Subhan.A. 2017. Pelaksanaan Transparansi Pemerintahan Daerah Dalam Pespektif Jaringan (Studi tentang Jaringan Organisasi yang terlibat dalam Penyediaan Informasi Laporan Anggaran melalui Website Pemerintah Provinsi Jambi Tahun 2016). Disetasi FISIP Universitas Padjadjaran Bandung. Halaman 53

[3] Provan,K.G. \& Kenis, P. 2008. "Modes of Network Governance: Structure, Management, and Effectiveness". Journal of public Administration Research and Theory. Hal:446

[4] Wasserman, M. Ellis,R. \& Wildavsky, A. 1990. Social Network Analysis: Methods and Application. New York: Cambrigde University Press. Halaman 4

[5] Haris,S. (ed).1998. Menggugat Pemilihan Umum Orde Baru. Buku Obor, Jakarta Hal. 10

[6] Wahidin.S. 2008. Mengawasi Pemilihan Umum Kepala Daerah , Hukum Pemerintahan Daerah. Yogyakarta: Pustaka Pelajar. Halaman 47.

[7] Miriam, Budiarjo. 2008. Dasar-dasar Ilmu Politik (Jakarta. PT.Gramedia Pustaka Umum. Halaman 368. 